\title{
EQUiLIBRIUM
}

Quarterly Journal of Economics and Economic Policy

2014 VOLUME 9 ISSUE 3, September

p-ISSN 1689-765X, e-ISSN 2353-3293

www.economic-policy.pl

Boratyńska K. (2014), The Theoretical Aspects of Measuring the Costs of Corporate Bankruptcy, "Equilibrium. Quarterly Journal of Economics and Economic Policy", Volume 9, Issue 3, pp. 43-57, DOI: $\underline{\text { http://dx.doi.org/10.12775/EQUIL.2014.017 }}$

Katarzyna Boratyńska*

Warsaw University of Life Sciences - SGGW, Poland

\section{The Theoretical Aspects of Measuring the Costs of Corporate Bankruptcy**}

JEL classification: $G 33$

Keywords: corporate bankruptcy; direct and indirect costs of corporate bankruptcy

\begin{abstract}
This article presents the issue of costs of enterprise bankruptcy. The purpose of this paper was to overview bibliography concerning the costs of corporate bankruptcy. According to literature, the author has pointed out that costs of bankruptcy can be divided into different groups, e.g. indirect and direct. The paper indicates the following corporate bankruptcy costs allocation criteria: time span, type of proceedings and the accounting perspective at the microeconomic level of analysis. The author has paid attention to models evaluation of costs of corporate bankruptcy. It is worth emphasizing that measurement of indirect costs of enterprises bankruptcy is a very complex issue.
\end{abstract}

(C) Copyright Institute of Economic Research \& Polish Economic Society Branch in Toruń Date of submission: April 2, 2013; date of acceptance: March 8, 2014

* Contact: katarzyna_boratynska@sggw.pl, Warsaw University of Life Sciences - SGGW, Faculty of Economic Sciences, Department of Economics and Organisation of Enterprises, 166 Nowoursynowska Street, 02-787 Warsaw, Poland

** The paper is published within the frame of the scientific project: Reasons for Bankruptcy of Food-processing Industry Enterprises in Selected Branches, decision number: UMO2011/01/B/HS4/00841 financed by Polish National Science Centre. 


\section{Introduction}

The issue of corporate bankruptcy costs is particularly important at the time of a financial crisis. The first theories of financial crises were presented by Paul Krugman and Barry Eichengreen in the 1980's. They claimed that financial crises occur mainly in developing countries with poorly developed financial markets. Paul Krugman said that if financial markets are poorly developed, the economy may be affected by significant imbalance. Mishkin and Stiglitz presented a theory stating that crises occur due to an information asymmetry (Toporowski, 2012, pp. 5-6).

The importance of the issue under discussion is clear if one considers the costs incurred in connection with declaring companies bankrupt or insolvent and the number of entities which may be affected by such a situation. Evaluation of the expected bankruptcy costs is one of the criteria which may facilitate the decision whether an entity in financial difficulties should continue as a going concern, be reorganised or go into liquidation.

The bankruptcy results in financial costs borne by the company, such as the loss of funds invested by shareholders, losses incurred by lenders on account of unpaid loans, and losses incurred by customers due to receivables which the bankrupt entity failed to pay. In addition, there are the social costs of bankruptcy, such as increased unemployment, falling competitiveness of the region (which are not discussed in this paper).

Related academic literature concerning the Polish economy includes very few papers whose authors make attempts at classifying and calculating bankruptcy costs. Therefore, it would seem that the subject matter requires a more thorough analysis. The purpose of this paper is to present a review of the hereto academic research with respect to the classification and the measurement of corporate bankruptcy costs.

\section{Methodology of the research}

According to E. Mączyńska (2013, p. 29), it is essential to differentiate between bankruptcy as an economic category and insolvency as a legal category. Bankruptcy entails a business failure, withdrawal from business activity, but not every bankrupt entity lodges a petition to the court to institute insolvency proceedings. Therefore, for the purpose of this paper, the author decided to use the term corporate insolvency costs while assessing the legal aspects (in particular the types of insolvency costs specified in the Insolvency and Reorganisation Law Act), and the term corporate bankruptcy costs in order to analyse the economic aspects of the phenomenon. 
Apart from the review and comparative/descriptive analysis of the hereto academic research with respect to the classification and the measurement of corporate bankruptcy costs, this paper concentrates on presenting its own concept of classifying bankruptcy costs at the microeconomic level. It includes the following division criteria: the time span, the type of proceedings and the accounting perspective. At this stage of research the Author used mainly the following methods: analysis and synthesis.

According to the Author's point of view, the level of bankruptcy costs may be measured using the following index: bankruptcy costs index $=(\mathrm{ex}-$ pected bankruptcy costs/ balance sheet total $1^{1}$ ) x $100 \%$, where:

Expected costs of bankruptcy $=$ the probability of bankruptcy $\mathrm{x}$ corporate bankruptcy costs.

The amount of bankruptcy costs may be estimated using the Wilcox model and Tobin's q index.

It is worth to emphasize the scientific approach of measuring the costs of corporate bankruptcy presented by T. Strąk and P. Stępień (Strąk (ed.), 2004a, p. 285). T. Strąk and P. Stępien suggested the following model of estimating corporate bankruptcy costs:

$$
K u=K b+K p=K b+(W b-W l)
$$

where:

$K u$ - bankruptcy costs,

$K b$ - direct bankruptcy costs,

$\mathrm{Kp}-$ indirect bankruptcy costs,

$W b$ - potential gross market value,

$W l$ - liquidation value of the company's assets.

This model assumes that indirect bankruptcy costs are equal to the decrease in the expected wealth of the company's owners indicated as the difference between the company's potential gross market value and its liquidation value. The company's potential market value is the value which it would have if it did not experience payment difficulties. This value should reflect the return rate on an investment in an undertaking with a similar risk level.

${ }^{1}$ Instead of balance sheet total it can be also assumed market value of a company (Boratyńska, 2010, pp. 560-571). 


\section{The definition and classification of corporate bankruptcy costs}

Among the papers which largely contributed to the development of the bankruptcy costs theory were those of Baxter, Stiglitz, Kraus and Litzenberger (Warner, 1977, pp. 337-338). Baxter showed that in an economy without taxation, having exceeded a certain level of financial leverage, the market value of a company decreases due to bankruptcy costs. Stiglitz introduced the optimal capital structure formula. DeAngelo and Masulisa claimed that regardless of whether bankruptcy costs are high or low, the relative share prices are determined in equilibrium so that net tax benefits are exactly equal to the expected end values of bankruptcy costs. They took into consideration the costs of bankruptcy whose amount depends on the level of incurred debt. By contrast, Senbet and Haugen claimed that regardless of whether bankruptcy costs exist and regardless of their amount, they should have no influence on the capital structure in perfect market conditions. Results of empirical research concerning the issue of insolvency costs often lead to conflicting conclusions (Kwansa (ed.), 1995, pp. 340-342).

Harris and Raviv, as well as Rven and Vasoncellosa, recognised the bankruptcy cost theory as a trend within the capital structure theory. This theory is static, which means that the value of the capital required to finance a company is given, whereas the optimisation of its structure constitutes the principal problem.

Bankruptcy costs may also be specified as a key determinant of the company's debt price and capital structure. According to Haugen and Senbet, bankruptcy costs do not have any major impact, as people who assert their claims should have a possibility to negotiate outside the courtroom without influencing the company's value. Jensen observed that a company's capability to renegotiate claims outside the courtroom may be negatively influenced not only by conflicts between groups of creditors, but also by court decisions (Altman (ed.), 2006, p. 93).

So far, there have been numerous studies concerning direct bankruptcy costs conducted in the United States. These indicate that their absolute value is "large" while they constitute only a slight percentage of the company's value. Table 1 presents empirical results of estimated direct and indirect costs of corporate bankruptcy (Altman (ed.), 2006, pp. 99-100). 
Table 1. Estimates of direct and indirect costs of corporate bankruptcy

\begin{tabular}{|c|c|}
\hline Study & Estimated Costs \\
\hline \multicolumn{2}{|r|}{ Direct Costs } \\
\hline Altman (1984) & $\begin{array}{l}\text { Mean } 4 \% \text { (median } 1.7 \%) \text { of firm value just prior to } \\
\text { bankruptcy for } 12 \text { retailers; } 9,8 \%(6.4 \%) \text { for } 7 \text { industrial } \\
\text { firms }\end{array}$ \\
\hline Ang et al. (1982) & $\begin{array}{l}\text { Mean } 7.5 \% \text { (median 1.7\%) of total liquidating value of } \\
\text { assets }\end{array}$ \\
\hline Betker (1997) & $\begin{array}{l}\text { Prepackaged bankruptcies }- \text { mean } 2.85 \% \text { (median } \\
2.38 \% \text { ) of prebankruptcy total assets; traditional Chapter } \\
11 \mathrm{~s}-\text { mean } 3.93 \% \text { (median } 3.37 \%) \text {; exchange offers - } \\
2.51 \%(1.98 \%)\end{array}$ \\
\hline Bris et al. (2004) & $\begin{array}{l}\text { Chapter } 7 \text { : mean } 8.1 \% \text {, median } 2.5 \% \text { of prebankruptcy } \\
\text { assets } \\
\text { Chapter } 11 \text { : mean } 9.5 \% \text {, median } 2 \%\end{array}$ \\
\hline Gilson et al. (1990) & $\begin{array}{l}0.65 \% \text { average offer costs as a percentage of book value } \\
\text { of assets }(\max 3.4 \%)\end{array}$ \\
\hline $\begin{array}{l}\text { Lawless \& Ferris } \\
(1997)\end{array}$ & Average $6.1 \%$ of total assets at filing (median $1.1 \%$ ) \\
\hline $\begin{array}{l}\text { LoPucki \& Doherty } \\
(2004)\end{array}$ & $\begin{array}{l}\text { Mean professional fees equal } 1.4 \% \text { of assets at beginning } \\
\text { of case }\end{array}$ \\
\hline Lubben (2000) & $\begin{array}{l}\text { Cost of professional fees in Chapter } 11 \text { averages } 1.8 \% \\
\text { (median } 0.9 \% \text { ) of total assets at beginning of case; } 2.5 \% \\
\text { excluding prepacks }\end{array}$ \\
\hline $\begin{array}{lll}\begin{array}{l}\text { Tashjian } \\
(1996)\end{array} & \text { et } & \text { al. } \\
\end{array}$ & $\begin{array}{l}\text { Mean } 1.85 \% \text {, median } 1.45 \% \text { of book value of assets at } \\
\text { fiscal year-end preceding filing }\end{array}$ \\
\hline Warner (1977) & $\begin{array}{l}\text { Mean } 4 \% \text { of market value of firm one year prior to de- } \\
\text { fault }\end{array}$ \\
\hline Weiss (1990) & Mean $3.1 \%$ (median $2.6 \%$ ) of firm value prior to filing \\
\hline \multicolumn{2}{|r|}{ Indirect Costs } \\
\hline Altman (1984) & $10.5 \%$ of firm value measured just prior to bankruptcy \\
\hline $\begin{array}{l}\text { Andrare \& Kaplan } \\
(1998)\end{array}$ & $10 \%$ to $20 \%$ of firm value \\
\hline $\begin{array}{lll}\text { Opler } & \& & \text { Titman } \\
(1994)\end{array}$ & Financial distress costs are positive and significant \\
\hline Pulvino (1999) & $\begin{array}{l}\text { Prices received for sales of used aircraft by bankrupt } \\
\text { airlines are lower than prices received by distressed but } \\
\text { non-bankrupt firms }\end{array}$ \\
\hline
\end{tabular}

Source: Altman (ed.) (2006, pp. 95-96). 
Altman and Weiss estimated that direct bankruptcy costs constitute ca. $3 \%$ of the company's value. Warner estimated the net costs of bankruptcy of 11 railway lines. Altman estimated that direct and indirect bankruptcy costs often exceed $20 \%$ of the company's value. Altman was the first to provide a proxy methodology for measuring indirect costs of bankruptcy. For a sample of companies entering Chapter 11, he compares expected profits to actual profits for the three years prior to bankruptcy. Andrare and Kaplan calculated that indirect costs of bankruptcy constitute between 10 and $20 \%$ of the company's value (Table 1) (Altman (ed.), 2006, pp. 99100).

In Poland, the applied principle is to cover the costs of insolvency proceedings from the bankruptcy estate in the first place. Uncovered costs are borne by the bankrupt after the conclusion of proceedings. Courts dismiss petitions for insolvency if they deem that the bankrupt entity's assets are insufficient to cover such costs. The costs of insolvency proceedings include: court fees and expenses necessary to conclude the proceedings. Court fees in insolvency proceedings are fixed. In contrast to the fee on a petition in civil or commercial proceedings, these do not depend on the value of asserted claims. The amount of fees in insolvency, voluntary arrangement or reorganisation proceedings has been indicated in Art. 74-76 of the Court Fees in Civil Cases Act of 28 July 2005 (Official Journal No. 167, item 1398). Expenses relating to insolvency proceedings indirectly burden creditors and the bankrupt entity, even though they are not directly covered by either. They are covered from the bankruptcy estate, which means that if it is insufficient to fully satisfy both the creditors and the costs, the former will receive proportionately less and the debtor will end up with a proportionately larger debt.

Expenses relating to proceedings aimed both at the liquidation of the bankrupt entity' assets and at reaching a possible voluntary arrangement include:

- the remuneration of the liquidator, supervisor or administrator, their deputies and court-appointed legal representatives, if appointed; these also include all expenses borne by such individuals if approved by the judge-commissioner;

- the remuneration of individuals who, upon the judge-commissioner's consent, are employed by the liquidator, supervisor or administrator or who, upon the judge-commissioner's consent, are commissioned to perform certain tasks;

- liabilities on account of pension, disability and health insurance paid from the remuneration of the liquidator, supervisor, etc.;

- the costs of notices and announcements; 
- the costs of collecting evidence and testimonies;

- the costs of the creditors' meeting, expenses borne by the creditors' committee as well as the remuneration of the committee's members;

- the costs relating to the activity of the bankrupt entity's governing bodies, such as the supervisory board or the board of auditors (as individually calculated by the judge-commissioner).

Furthermore, expenses relating to insolvency proceedings aimed at liquidating the bankrupt entity's assets include:

- the costs of liquidating the bankruptcy estate (sale of the bankrupt entity's assets),

- the remuneration, social insurance premiums of employees working in the bankrupt company payable after the adjudication of insolvency, as well as severance pay and compensation due to such employees in connection with the termination of employment contracts;

- taxes and other public contributions (e.g. stamp duty) payable for the period after the adjudication of insolvency;

- the costs of the business activity conducted by the liquidator after the adjudication of insolvency ${ }^{2}$.

Insolvency costs may be defined as a reasonably anticipated decrease, during the reporting period, in reliably evaluated economic benefits which results in deteriorating the entity's financial condition and entails the creation of additional burdens which determine the future insolvency process by way of decreasing the value of assets or increasing the value of liabilities and provisions (Chłodnicka, 2007, p. 41). Insolvency costs may be recognised in line with different approaches. According to Chłodnicka, they may be divided by means of a system of links between the costs and the insolvency process areas of activity. Therefore, one may distinguish: the costs of the principal insolvency activity, the costs of the administrative insolvency activity and the costs of the financial insolvency activity (Chłodnicka, 2004a, pp. 139-140).

Having analysed the related literature, the author proposes to divide bankruptcy costs into direct and indirect. Direct bankruptcy costs cause the sum of cash flows to decrease with reference to the level on which it would be if the process had not occurred. Direct bankruptcy costs include: legal and administrative expenses borne in connection with the bankruptcy as well as with the sale of assets, which in certain cases constitute a considerable share of the company's value; the costs relating to the changing value of the assets in time. Indirect bankruptcy costs concern the reaction of various parties to the possibility of this process taking place. The company's

\footnotetext{
${ }^{2}$ Insolvency and Reorganisation Law Act of 28 February 2003 (Official Journal No. 60, item 535).
} 
managers and employees, who are often laid off when the entity goes bankrupt, may undertake actions which in the short term improve its financial condition (liquidity in particular) but which also decrease its market value. For instance, they can sell assets at an undervalued price, neglect proper maintenance of machines in order to freeze costs, or produce lower quality goods. On the other hand, clients may decrease the number and value of orders, suppliers may demand immediate payment for goods, and banks may increase credit interest rates. The increased probability of bankruptcy itself results in creating costs which would not occur without such a threat. In order to measure the indirect costs of bankruptcy, one may, among other things, compare the forecasted sales revenue and the forecasted profit with actually obtained figures. It must be stressed here that it is very difficult to measure the indirect bankruptcy costs, which refer to cooperation with customers and suppliers. Sales revenue decreases due to lack of trust and fear of decreased quality of services.

The concept of classifying bankruptcy costs at the microeconomic level, which has been presented in Table 2, includes the following division criteria: the time span, the type of proceedings and the accounting perspective.

Table 2. The concept of classification of corporate bankruptcy costs

\begin{tabular}{|c|c|}
\hline \multirow{2}{*}{$\begin{array}{c}\text { Cost } \\
\text { allocation } \\
\text { criterion }\end{array}$} & $\begin{array}{l}\text { Level of analysis: } \\
\text { Microeconomic }\end{array}$ \\
\hline & Bankruptcy costs \\
\hline \multicolumn{2}{|r|}{ 1. time span } \\
\hline $\begin{array}{l}\text { a) caused prior } \\
\text { to the adjudica- } \\
\text { tion of insol- } \\
\text { vency (during } \\
\text { the so-called } \\
\text { financial diffi- } \\
\text { culties) }\end{array}$ & $\begin{array}{l}\text { Direct: } \\
\text { - } \text { additional costs of legal and administrative services, } \\
\text { - costs of additional interest due to delayed payment of liabilities, } \\
\text { - increased credit interest rate, } \\
\text { - costs of evaluating assets and liabilities as pledge, } \\
\text { - costs of depreciation of assets due to sell-off, } \\
\text { - costs of amending and renegotiating contracts, } \\
\text { Direct: } \\
\text { - managers in a company under the threat of insolvency may under- } \\
\text { take actions which allow them to survive in the short term but which } \\
\text { are unbeneficial from the perspective of the company's value; } \\
\text { - once the clients and suppliers have learned of the company's condi- } \\
\text { tion, they undertake actions aimed at limiting their risk, which re- } \\
\text { sults in deteriorating the conditions in which the company operates; } \\
\text { - agency costs relating to the conflict between shareholders and credi- } \\
\text { tors; the costs of lost performance and the creditors' supervision } \\
\text { costs; }\end{array}$ \\
\hline
\end{tabular}


Table 2 Continued

\begin{tabular}{|c|c|}
\hline \multirow{2}{*}{$\begin{array}{c}\text { Cost } \\
\text { allocation } \\
\text { criterion }\end{array}$} & $\begin{array}{l}\text { Level of analysis: } \\
\text { Microeconomic }\end{array}$ \\
\hline & Bankruptcy costs \\
\hline \multicolumn{2}{|r|}{ 1. time span } \\
\hline & $\begin{array}{ll}- & \text { contractual costs resulting from the changed investment risk; } \\
- & \text { lost sales and profits; } \\
- & \text { deterioration of employees' working conditions, }\end{array}$ \\
\hline $\begin{array}{l}\text { b) during in- } \\
\text { solvency pro- } \\
\text { ceedings }\end{array}$ & $\begin{array}{l}- \text { disputes among creditors may hinder the sale of assets, thus decreas- } \\
\text { ing their value; } \\
\text { - } \text { preparation costs (of court proceedings); } \\
- \text { insolvency proceedings costs: the costs of remuneration for the } \\
\text { liquidator and his/her co-workers, costs of notices and announce- } \\
\text { ments, costs relating to liquidating assets (costs of remuneration for } \\
\text { the company's employees together with severance pay, costs of ap- } \\
\text { praisal and auction of the assets, legal costs, enforcement costs, oth- } \\
\text { er). }\end{array}$ \\
\hline $\begin{array}{l}\text { c) after the } \\
\text { liquidation of } \\
\text { assets or volun- } \\
\text { tary arrange- } \\
\text { ment with } \\
\text { creditors }\end{array}$ & $\begin{array}{l}- \text { borne by creditors, e.g. due to prolongation of the receivables' pay- } \\
\text { ment term or redemption of a part of debt }\end{array}$ \\
\hline \multicolumn{2}{|r|}{ 2. type of proceedings } \\
\hline a) liquidation & $\begin{array}{l}\text { The costs of remuneration for the liquidator and his/her co-workers, } \\
\text { costs of notices and announcements, costs relating to liquidating assets } \\
\text { (costs of remuneration for the company's employees together with sev- } \\
\text { erance pay, costs of appraisal and auction of the assets, legal costs, } \\
\text { enforcement costs, other). }\end{array}$ \\
\hline $\begin{array}{l}\text { b) reorganisa- } \\
\text { tion }\end{array}$ & - costs borne by creditors \\
\hline \multicolumn{2}{|r|}{ 3. the accounting perspective } \\
\hline a) accounting & $\begin{array}{l}\text { It should be stressed that accounting records lack solutions relating to } \\
\text { insolvency costs. Although introducing an additional group of ac- } \\
\text { counts, such as insolvency costs, would fit into the framework of the } \\
\text { current reporting law, practice shows that the most frequent solution is } \\
\text { to copy the model account plan and adapt it to the company's needs, if } \\
\text { necessary. }{ }^{3} \text {. }\end{array}$ \\
\hline
\end{tabular}

Source: Boratyńska (2009, p. 36).

\footnotetext{
${ }^{3}$ The concept of costs of corporate bankruptcy as a part of traditional costs account was presented by Chłodnicka (2004b, pp. 7-14).
} 


\section{Determinants influencing the level of bankruptcy costs}

The amount of bankruptcy costs depends on external factors relating to the company, as well as on internal factors which it may directly influence. External factors include mainly the business cycle phase of the economy. It is worth noting that, among other things, due to the global financial crisis, the number of bankruptcies among banks and companies has increased. The amount of bankruptcy costs depends largely on the size and "age" of the company, its employment structure and the level of human capital, assets' structure, type of activities conducted, and competence of people responsible for the liquidation.

From the economic perspective, corporate bankruptcies should purify the market of inefficient entities. As the company grows, the risk of bankruptcy decreases; however, the economic costs of bankruptcy increase. Considering only the company's level, the legal costs of insolvency do not depend on its size measured, for instance, using the balance sheet total, turnover or market capitalisation. From the economic perspective, the costs of insolvency in the case of small scale undertakings are lower compared to those in the case of "large entities". The risk of insolvency in the case of small companies is greater than in the case of large ones (Figure 1). The scale of activities may be measured by: the number of employees, production size, balance sheet total, turnover, and market capitalisation.

Figure 1. Bankruptcy costs - the macroeconomic approach (costs from the economic perspective)

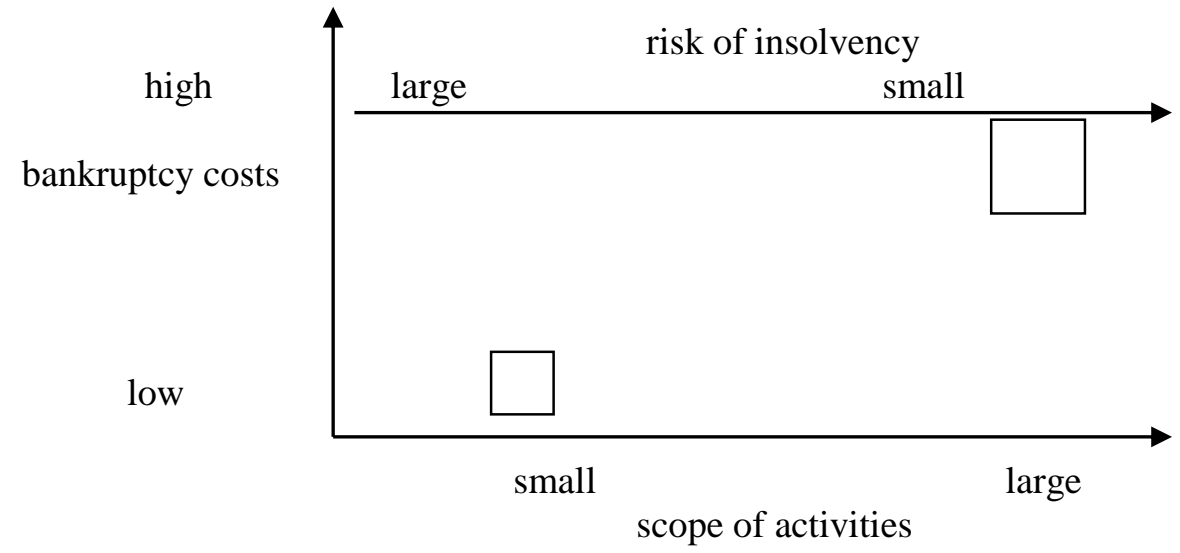

Source: own research. 
The size of an undertaking measured by the balance sheet total influences the level of bankruptcy costs, for as the value and quantity of assets held increase, the amount of costs increases in absolute terms and decreases in relative terms - they constitute an ever lower per cent. As the number of employees increases due to the applicable labour legislation (the obligation to provide severance pay), the costs of insolvency increase.

Bankruptcy costs also depend on the number of years of the company's operations on the market. The longer it operates, the higher the potential bankruptcy costs. Undertakings which have operated for a long period of time usually have a recognisable brand, trademarks, know-how, experienced staff; these components may have a considerable value, but only if the company continues to operate. In the case of liquidation, their value is very low.

\section{Modelling and measuring the costs of corporate bankruptcy}

In 2012, the cost of insolvency proceedings expressed as a per cent of the bankruptcy estate was the lowest in countries such as Colombia, Kuwait, Norway, Singapore, Belgium, and Canada (less than 4\%) while the highest values were shown in Africa, Liberia, and the Ukraine (over 42\%) (Table $3)$.

The Wilcox model allows making a simplified appraisal of the company's liquidation value.

Liquidation value of assets $=$ value of cash + value of securities $+0.7 \mathrm{x}$ receivables +0.5 carrying value of outstanding assets

Comparing the company's gross value estimated in this manner with its market value allows for estimating the indirect costs of insolvency. The direct costs of insolvency are calculated based on the evaluation of the provision which would have to be created in the case of an incapacity to continue operations. A more detailed model of estimating the liquidation value was proposed in the Polish literature by R. Machała. Tobin's q model is the ratio of the market value of the company's assets to the current assets' replacement cost. Wilcox's and Tobin's models determine the losses incurred due to the sale of an entity accompanied with its early liquidation caused by a difficult financial condition (Strąk (ed.), 2004a, p. 285). 
Table 3. Cost of corporate insolvency as a percentage of estate

\begin{tabular}{|l|l|l|c|}
\hline \multicolumn{4}{|c|}{ Cost (\% of estate) } \\
\hline Colombia & 1 & Samoa & 38 \\
\hline Kuwait & 1 & Solomon Islands & 38 \\
\hline Norway & 1 & Vanuatu & 38 \\
\hline Singapore & 1 & Venezuela, RB & 38 \\
\hline Armenia & 4 & Sierra Leone & 42 \\
\hline Bahamas, The & 4 & Ukraine & 42 \\
\hline Belgium & 4 & Liberia & 43 \\
\hline Brunei Darussalam & 4 & Rwanda & 50 \\
\hline Canada & 4 & Czad & 60 \\
\hline Denmark & 4 & $\begin{array}{l}\text { Central African Repu- } \\
\text { blic }\end{array}$ & 76 \\
\hline
\end{tabular}

Source: Resolving Insolvency w: Doing Business (2012, p. 4).

The model proposed by Strąk and Stępien (it is presented precisely in methodology of the research part) underlines the impact of bankruptcy costs on the company's value. If there are no financial difficulties, the undertaking's value is the market value. In the case of forced liquidation, the company's owners and creditors receive only Wl-Kb. Therefore, the difference between the company's market value estimated with the assumption of a going concern and lack of financial difficulties and the net proceeds (proceeds from the forced sale of assets decreased by the direct bankruptcy costs) from the company's liquidation constitutes the entire cost of bankruptcy. Bankruptcy costs may burden not only the company's owners but also its creditors. If $\mathrm{Wl}-\mathrm{Kb}<\mathrm{D}$ (where $\mathrm{D}$ - company's liabilities), the bankruptcy costs are also borne by the creditors (Strąk (ed.), 2004b, pp. 296297).

Strąk and Stępień (2004b, pp. 276-277) analysed files of insolvency cases heard by district courts in Koszalin, Słupsk and Szczecin. They stressed that the evaluation of costs performed by judge-commissioners focuses only on the on-going verification of the appropriateness of expenses incurred by the liquidator. There is no comparison of insolvency costs between different cases, neither is there any assessment of the total costs against the obtained effects. Strąk and Stępień (2004b, pp. 277-278, p. 282) collected empirical data concerning 41 undertakings (the average value of assets indicated that the research concerned small entities). The average 
length of insolvency proceedings in the analysed sample was 2.5 years. Direct insolvency costs constituted 50\% of the carrying value of assets as at the insolvency adjudication date and ca. 60\% of their market value (proceeds to the estate). The amount of direct insolvency costs depends mainly on the size of the undertaking. The liquidator's remuneration constitutes ca. $11 \%$ of direct insolvency costs and $6 \%$ of the proceeds to the estate.

S. Morawska ${ }^{4}$ (2012, pp. 11-60) presented results of the research conducted in insolvency courts in the Białystok appellate area, the District Court for Wrocław Fabryczna, 8th Commercial Division for Insolvency and Reorganisation, the District Court for Cracow-Sródmieście in Cracow, 8th Commercial Division for Insolvency and Reorganisation and the District Court for the capital city of Warsaw, and the 10th Commercial Division for Insolvency and Reorganisation. A total of 729 insolvency case files were examined. As far as the author knows, this has been the first research into studying the efficiency of insolvency proceedings on such a broad scale to be conducted in Poland. Costs of proceedings, construed as the costs of liquidating the estate and the costs of operations against the bankruptcy estate were the highest in the case of proceedings conducted in the District Court in Białystok, i.e. 40\%, while the lowest result was found in the case of proceedings conducted in the District Court for Wrocław Fabryczna, i.e. $31 \%$. According to the research conducted by S. Morawska in the aforesaid respect, the efficiency of insolvency proceedings in Poland was lower compared to the results published by the World Bank in its Doing Business reports, e.g. in 2011 the costs were reported to constitute on average $15 \%$ of the company's assets. The research conducted by $\mathrm{S}$. Morawska leads to a conclusion that the share of the liquidator's remuneration in the bankruptcy estate fund was low and did not exceed $4 \%$. The relationship between the recovered receivables and the bankrupt entity's debt was the highest in the case of insolvency proceedings conducted in the District Court for Wrocław Fabryczna, i.e. 34\%, and the lowest (9\%) in the District Court for Cracow-Śródmieście in Cracow (Morawska, 2012, pp. 46-47).

\footnotetext{
${ }^{4}$ Compare also research project results entitled Efektywność procedur upadtości conducted under Elżbieta Mączyńska supervision, number: N N112180739.
} 


\section{Conclusions}

Based on the analysis of the data presented in this paper one may draw the following summary conclusions:

1. Bankruptcy costs are usually divided into direct and indirect. The direct costs include: legal and accounting costs, the expenses on hiring restructuring advisors and other experts. Lawyers' remuneration often constitute a considerable share of such costs. The indirect costs cover a large range of costs of lost benefits, e.g. the sales and profits in many companies fall since clients refuse to cooperate with a company which may go bankrupt. The research conducted so far indicates that indirect bankruptcy costs are very difficult to estimate.

2. It is also possible to classify the bankruptcy costs according to the following criteria: time span, type of proceedings and the accounting perspective.

3. Model research concerning the issue discussed here, which was performed in Poland by T. Strąk and P. Stępień, stresses the significance and importance of direct and indirect costs of bankruptcy. It shows that the level of direct insolvency costs depends mainly on the size of the undertaking.

4. The subject of the study concerning costs of corporate bankruptcy deserves for further research in the future.

\section{References}

Altman I.E., Hotchkiss E. (2006), Corporate financial distress and bankruptcy. Predict and avoid bankruptcy, analyze and invest in distressed debt, Wiley, Hoboken, New Jersey, http://dx.doi.org/10.1002/9781118267806.

Art. 74-76 of the Court Fees in Civil Cases Act of 28 July 2005 (Official Journal No. 167, item 1398).

Boratyńska K. (2009), Pomiar i klasyfikacja kosztów upadtości przedsiębiorstw na świecie $i$ w Polsce, „Wieś Jutra”, No. 3.

Boratyńska K. (2010), Pomiar bezpośrednich i pośrednich kosztów bankructwa przedsiębiorstwa [in:] Sobiech J. (ed.), Kierunki zmian $w$ finansach przedsiębiorstwa, Zeszyty Naukowe Uniwersytetu Ekonomicznego w Poznaniu nr 142, Poznań.

Chłodnicka H. (2004a), Identyfikacja i systematyka kosztów upadtości, „Prace Naukowe Akademii Ekonomicznej we Wrocławiu”, No. 1039.

Chłodnicka H. (2004b), Koszty upadtości w tradycyjnym rachunku kosztów - próba ich wyeksponowania, „Zeszyty Teoretyczne Rachunkowości”, numer specjalny, Vol. 21(77). 
Chłodnicka H. (2007), Regulacje prawne procesu upadłościowego a potrzeby ich zmian, „Forum Rachunkowości”, No. 3.

Insolvency and Reorganisation Law Act of 28 February 2003 (Official Journal No. 60, item 535).

Kwansa F.A., Cho M.H. (1995), Bankruptcy cost and capital structure: the significance of indirect cost, "Int. Hospitality Management", Vol. 14, No. 3/4.

Mączyńska E. (2013), Wprowadzenie [in:] Mączyńska E. (ed.), Procesy upadtościowe $i$ naprawcze $w$ Polsce na tle doświadczeń Unii Europejskiej, Oficyna Wydawnicza SGH w Warszawie, Warszawa.

Morawska S. (2012), Wyniki badań przeprowadzonych w zakresie efektywności procedur upadtościowych $w 2011$ r. w wybranych sadach upadtościowych [in:] Babiarz-Mikulska K., Czapracka A., Morawska S. (ed.), Ocena efektywności procedur upadtościowych wobec przedsiębiorców. Aspekty prawne, ekonomiczne i organizacyjne, Difin, Warszawa.

Research project results entitled Efektywność procedur upadtości conducted under Elżbieta Mączyńska supervision, number: N N112180739, E. Mączyńska, S. Morawska, A. Czapracka, W. Baran.

Resolving Insolvency (2012), Doing Business 2012, Retrieved: http://www.doingbusiness.org/reports/global-reports/ /media/GIAWB/Doing $\%$ 20Business/Documents/Annual-Reports/English/DB12-Chapters/ResolvingInsolvency.pdf (15.01.2013).

Strąk T., Stępień P. (2004a), Modelowanie kosztów bankructwa, „Zeszyty Naukowe Uniwersytetu Szczecińskiego" No. 385, Finanse, Rynki Finansowe, Ubezpieczenia No. 1.

Strąk T., Stępień P. (2004b), Bezpośrednie i pośrednie koszty bankructwa, „Zeszyty Naukowe Uniwersytetu Szczecińskiego" No. 385, Finanse, Rynki Finansowe, Ubezpieczenia No. 1.

Toporowski J. (2012), Nauka o kryzysach finansowych, „Biuletyn Polskiego Towarzystwa Ekonomicznego", No. 5.

Warner J.B. (1977), Bankruptcy Costs: Some Evidence, "Journal of Finance”, Vol. 32, No. 2. 